\section{Pentazocine in Thyroid Failure}

SIR,-Mr. W. M. Gould (29 January, p. 313) described a case in which there was C.N.S. disturbance due to pentazocine administration. It is important to emphasize that in certain circumstances even a single dose of pentazocine may be harmful.

We recently admitted a 50-year-old married woman who was complaining of rightsided chest pain. She had a right-sided effusion and was clinically hypothyro.d with pale, fine skin, absent body hair, and B.P. $160 / 90$. She had had a difficult pregnancy 24 years before, followed by a severe post-partum haemorrhage. She did not breast feed and her menses never resumed. For two years previous to this admission her relatives noticed slowing of activity and mentation. Relevant investigations showed Hb. $9.9 \mathrm{~g} / 100 \mathrm{ml}$., E.S.R. $78 \mathrm{~mm}$ in $1 \mathrm{hr}$ moderate hypochromia and anisocytosis, P.B.I. $1.5 \mu \mathrm{g} / 100 \mathrm{ml}, \mathrm{T} 42.1 \mu \mathrm{g} / 100 \mathrm{ml}$ and free thyroxine index 1.5-these last three being all low values. Random plasma cortisol was $9.4 \mu \mathrm{g} / 100 \mathrm{ml}$ and $\mathrm{B}_{1 \mathrm{~g}}$ folate, electrolytes, and glucose tolerance were normal. Cholesterol was $264 \mathrm{mg} / 100$ $\mathrm{ml}$, lactic dehydrogenase 425 I.U./l. Skul $x$-ray was normal. The chest $x$-ray showed right-sided consolidation and effusion compatible with either pneumonia or pulmonary embolism.

She was treated with ampicillin $500 \mathrm{mg}$ six-hourly, but because of severe rightsided chest pain was given $60 \mathrm{mg}$ of pentazocine orally. Forty-five minutes after the pentazocine her temperature had fallen from $38^{\circ} \mathrm{C}$ (oral) to $36^{\circ} \mathrm{C}$ (rectal). She was drowsy, disorientated, and cyanosed with a respiratory rate of $3 / \mathrm{min}$ and irregular, with poor expansion and air entry. B.P. was 90/60. Peripheral pulses were not palpable, apex rate was $80 / \mathrm{min}$, with normal heart sounds and no signs of congestive heart failure. An E.C.G. showed low voltage QRS, depressed ST segment, and T wave inversion over the left ventricle, together with $\mathrm{U}$ waves. At that time $\mathrm{Po}_{2}$ was $49 \mathrm{~mm} \mathrm{Hg}$ with $\mathrm{PCO}_{2}$ of $52 \mathrm{~mm} \mathrm{Hg}$, $\mathrm{pH} 7 \cdot 27$, and standard bicarbonate 22 $\mathrm{mEq} / \mathrm{l}$. Blood sugar was within normal limits.

Clinically she showed a picture of respiratory depression and severe myxoedema. She was given $20 \mu \mathrm{g}$ of tri-iodothyronine and $100 \mathrm{mg}$ of hydrocortisone intravenously, followed by $1 \mathrm{~g}$ of hydrocortisone and 80 $\mu \mathrm{g}$ of tri-iodothyronine intravenously over the following 24 hours. Two hours after the episode, her respiratory rate was $9 / \mathrm{min}$ with a minute volume of $4,100 \mathrm{ml} / \mathrm{min}$, and blood gases had returned to normal on a $35 \%$ oxygen supplement. Her temperature remained at $34^{\circ} \mathrm{C}$ (rectal) for 36 hours. Her level of consciousness improved over this period, but she then became overexcited. She was maintained on intravenous therapy for 48 hours, then weaned slowly on to oral thyroxine and steroids. Her remaining stay in hospital was uneventful.

While it is well known that infection can precipitate myxoedema precoma in susceptible people, we consider that this patient's episode of respiratory failure and hypothermia can be directly related to the administration of pentazocine. Previously reported side effects of pentazocine ${ }^{1}$ have included respiratory depression, drowsiness, or excitement, with tachycardia and a rise in blood pressure, preceded sometimes by a transient fall in systolic pressure. ${ }^{23}$ However, in this patient there was a marked fall in blood pressure, both systolic and diastolic. We consider that in pituitary or thyroid disease pentazocine and related products should be used with extreme caution.

We wish to thank Dr. D. A. Williams for allowing us to report this case.

-We are, etc.,

Bethan M. Evans

JAMES DUNNE

University Hospital of Wales,

IVOR SURVEYOR

Llandough Hospital,

1 British Medical foumal, 1970, 2, 409

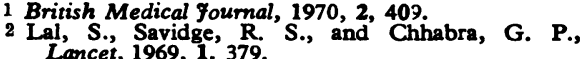
3 Scott, M. E., and Orr, R., Lancet, 1969, 1, 1065.

\section{Verapamil in Cardiac Arrhythmias}

SIR,-The recent article by Dr. L. Schamroth and others (11 March, p. 660) on the use of verapamil in supraventricular arrhythmias confirmed our very favourable impressions of its great value which we have learned over the past year since he introduced us to its use during a visit to Cape Town. Dr. C. B. Boothby and others (6 May, p. 349), however, remind us of similar experiences of its potential danger in digitalized patients.

The first, a 45-year-old man with terminal ischaemic cardiac failure had a heart transplant performed on 10 May, 1971. Twentytwo days later he developed atrial flutter with 2:1 A-V block. $1.75 \mathrm{mg}$ digoxin was given over 24 hours without effect. A tes dose of quinidine $(200 \mathrm{mg})$ was given with the intention of quinidine conversion. Two hours later it was elected to try intravenous verapamil and $2.5 \mathrm{mg}$ were given ove approximately half a minute. He was observed for two minutes before increasin A-V block developed. Within the next few minutes his $2: 1 \mathrm{~A}-\mathrm{V}$ block increased to 10:1 block with a ventricular rate of 30 pe minute. Over the next fifteen minutes the A-V block diminished to its former state. Other drugs being given at the time of this treatment included prednisolone, azathioprine, antilymphocyte globulin, Lugol's iodine, clofibrate, and heparin. Serum electrolytes were normal at the time. Later the same day the patient was uneventfully converted to sinus rhythm under diazepam sedation with a single shock of 50 watt secs. The patient has had no subsequent arrhythmias and has since returned to full employment in good health.

The second patient, a 63-year-old man, was admitted in cardiogenic shock and pulmonary oedema with rapid atrial fibrillation, following an extensive myocardial infarction. Because of bifascicular block a temporary transvenous pacemaker was inserted. Treatment with oxygen, morphine, aminophylline, diuretics, and dignxin resulted in considerable clinical improvement with associated slowing of his ventricular rate to approximately 100 per minute within 24 hours. By 36 hours he had developed atrial flutter with a ventricular rate of approximately 130 per minute. $10 \mathrm{mg}$ verapamil were given intravenous over two to three minutes following which he developed ventricular standstill within a minute with loss of consciousness. His pacemaker, which had been switched off at the time, was activated with immediate ventricular capture and recovery. He remained in complete heart block over the next 24 hours and was subsequently successfully cardioverted to sinus rhythm with a normal P-R interval. His hypotension then worsened and he died the following day.

At the time we attribured the dramatic increase in A-V block in the first patient after only $2.5 \mathrm{mg}$ verapamil to an unusual situation in which cardiac denervation following transplantation may have been implicated. Our second patient had bifascicular block and was known to be a candidate for complete heart block, although there was a close temporal relationship with the administration of verapamil.

In retrospect, however, both patients were digitalized and the second man was possibly over-digitalized as evidenced by the recent conversion of atrial fibrillation to flutter. While we have given verapamil to numerous other patients who have been digitalized, as have Dr. Schamroth and his colleagues, our experiences in conjunction with those quoted by Dr. Boothby and others should lead to preparedness for resuscitation in patients receiving verapamil when such patients are on digitalis or beta blockers or where A-V conduction disturbances already exist.-We are, etc.

H. SACKS

Cardiac Clinic

B. M. KENNELLY

chuur Hospital,

Grope Town, South Africa

\section{Vasectomy}

SIR,-Unlike Dr. P. Konstam (27 May, p. 531) I have not been impressed by a tendency of wound complications to follow vasectomy performed through a scrotal in cision, and see no need for using an inguinal approach.

I undertake vasectomy under local anaesthesia through bilateral sorotal incision approximately $0.75 \mathrm{~cm}$ in length. The in cidence of haemorrhage and sepsis in 600 cases has been minimal. The minor nature of the procedure has advantages for use in a clinic of this type where twelve operations are performed in three hours.

However, I feel the type of suture material used to appose the skin edges in this situation may be relevant, for minor skin sepsis initially experienced when catgut was used has no longer been a problem following the use of fine non-absorbable sutures, which are removed after four days. -I am, etc.,

Kingston Contraceptive Clinic,

IAN CRAFT

Chessington, Surrey

\section{New Consultant Contract}

SIR,-Dr. P. N. Coleman's letter (27 May, p. 532) concerning a new contract for consultants which the Central Committee for Hospital Medical Services hope to negotiate deserves the closest attention. The implications of the proposals to whole-time consultants are considerably disquieting.

The C.C.H.M.S. propose that the basic commitment should be limited to ten sessions, certain work, including emergency 